\title{
ILMU USHUL FIQH (Kajian Ontologis dan Aksiologis)
}

\author{
M uhyar Fanani \\ (D osen Pascasarjana IA IN W alisongo Semarang, email: \\ muhyarfanani@yahoo.com)
}

\begin{abstract}
A bstract:
At first, Islamic law is a law which encompasses all aspects of life. In reality, Islamic law only becomes a marginal law. M ost of observers said that its fault is on the methodology aspect that is Islamic legal theory. Therefore, the effort of this theory development cannot be avoided. The figures of Islamic legal theory such as Fazlur Rahman (Pakistan), Mahmoud Muhammad Taha (Sudan), Abdullahi A hmed an-Na'im (SudanUSA), Muhammad Sa'id A symawi (Egypt), and Abd alA. Sulaymân (A rab-Malay) remind Moslems to develop this theory. This writing tries to accept their invitation based on philosophy perspective, that is a perspective which has not been used by them.
\end{abstract}

\section{Keywords:}

Ushul fiqh, aksiologi, ontologi, dan epistemologi.

\section{Pendahuluan}

Dalam kacamata filsafat ilmu, pengembangan suatu ilmu hendaknya berangkat dari pengembangan epistemologinya1 terlebih

\footnotetext{
1 Epistemologi adalah cabang filsafat yang mempelajari dan mencoba menentukan kodrat dan ruang lingkup pengetahuan, pengandaian-pengandaian dan dasarnya serta pertanggungjawaban atas pernyataan mengenai pengetahuan yang dimiliki. Epistemologi itu sendiri berasal dari bahasa Yunani, yakni epistem dan logos. Epistem dimaknai sebagai pengetahuan atau kebenaran, sedangkan logos dimaknai sebagai pikiran, kata atau teori. Dengan demikian, epistemologi secara etimologis dimaknai sebagai teori pengetahuan. Lihat M. A min A bdullah, "Aspek Epistemologis Filsafat Islam", dalam Irma Fatimah (ed.), Filsafat Islam: Kajian Ontologis, Epistemologis, A ksiologis, H istoris, Prospektif (Yogyakarta: LESFI, 1992), hlm., 28 dan Kenneth T.
} 
Muhyar F anani

dahulu. Hal ini berdasarkan oleh kenyataan bahwa prestasi besar science di era modern ini tercapai berkat perdebatan sengit tentang epistemologi yang terjadi di Barat sejak renaissance dulu. Kenyataan ini semakin kuat kebenarannya, bila kita bertanya mengapa di abad modern ini, science dipegang oleh Barat, bukan umat Islam? Jawabannya adalah karena perdebatan gencar epistemologismemang terjadi di Barat, Umat Muslim belum pernah melakukan perdebatan serupa secara serius.

Dengan menggunakan sudut pandang filsafat ilmu, maka dapat diketahui bahwa dalam upaya mengembangkan ilmu ushul fiqh, kita perlu menelusuri terlebih dahulu epistemologi apa yang telah dimiliki oleh ilmu ini. Tujuannya adalah agar upaya pencarian epistemologi baru nanti memiliki dasar pijak yang memadai.

\section{Makna Filosofis IImu Ushul Fiqh}

IImu ushul fiqh merupakan metodologi pemikiran Islam yang terpenting. la menampilkan dasar-dasar rasional bagi pemikiran Islam. Walaupun ilmu ushul fiqh resmi disusun oleh al-Syâfi î, tapi ilmu ini sebagai disiplin tersendiri telah dibangun oleh tâbi în dan tâbi`al-tâbi în.²

IImu ushul figh juga merupakan komponen metodologi terpenting yang dipakai oleh ilmu-ilmu keislaman klasik. la disebut juga sebagai metodologi tradisional Islam. ${ }^{3}$ Oleh karena itu, ilmu ini adalah produk khas umat Islam, yang tidak dimiliki oleh Barat maupun peradaban manapun di dunia ini.4

Menurut para pakar, ilmu ini tersusun dari gabungan berbagai disiplin ilmu, yakni logika Aristoteles, kaidah bahasa Arab, teologi

Gallagher, Epistemologi Filsafat Pengetahuan, terj. P. Hardono Hadi (Yogyakarta: Kanisius, 1994), hlm., 5.

2Abdul Hamîd Abû Sulaimân, Crisis in the M uslim M ind (Herndon-Virginia: IIIT, 1414/ 1993), hlm. 37.

3 lbid., 36.

4Ali Garisyah, M etode P emikiran Islam (M anhaj at-Tafkir al-Islami) (Jakarta: Gema Insani Press, 1989), hlm. 56. 
(ilmu kalam), ilmu figh, dan ilmu-ilmu al-Qur ân dan Sunnah. ${ }^{5}$ Bahkan menurut al-Ghazâlî, ilmu ushul fiqh merupakan ilmu yang paling tinggi derajatnya, karena merupakan gabungan dari dua jenis ilmu yakni ilmu naql murni seperti al-Qur'ân, Hadits, dan ilmu 'aql murni seperti logika (manthîq). ${ }^{\circ}$ Namun, benarkah al-Ghazâlî menganggap bahwa epistemologi ilmu ushul fiqh adalah gabungan antara naql dan 'aql, masih merupakan pertanyaan yang perlu diteliti lebih lanjut. Mengapa? Karena epistemologi ushul berbeda dengan epistemologi hukum Islam. Epistemologi ushul berbicara tentang sumber, watak pengetahuan, dan kriteria kebenaran dari sebuah ilmu yang bernama ilmu ushul, sementara epistemologi hukum Islam berbicara tentang sumber-sumber hukum Islam. Mengingat ilmu ushul adalah ilmu tentang kaidah (dalil kullî), maka epistemologi ushul tiada lain adalah sumber, watak pengetahuan, dan kriteria kebenaran yang dipergunakan oleh kaidah (dalil kullî fiqh). Benarkah untuk urusan kaidah-kaidah dalam menangkap maksud al-Qur'ân, ayat al-Qur'ân menjadi sumber pengetahuan? Bukankah kaidahkaidah itu diciptakan oleh manusia? Bukankah kaidah-kaidah itu sesungguhnya adalah hasil ijtihâd umat manusia zaman al-Syâfi'î?

Unsur logika Aristoteles terlihat pada cara kata menentukan makna, pembahasan yang bersifat konseptual dan definitif, validitas kesimpulan yang berdasarkan pada penalaran induktif, pembahasan tentang dalil, pembahasan tentang ta' ârud al-adillah,7 dan lain-lain. ${ }^{8}$ Secara historis, logika A ristoteles (384-322 SM) diadopsi orang A rab Islam melalui penterjemahan. Penterjemah logika pertama adalah Yohana b. Patrik (I. 815) dengan judul M a'qulat A syarat li A risto. Akan tetapi, terjemahan paling sempurna baru muncul di tangan al-Farabi

5Tâha Jâbir al-Alwânî, Source M ethodology in Islamic Jurisprudence (Herndon, Virginia: International Instituteof IsImic Thought, 1415/ 1994), hlm. 5-6. Pendapat serupa baca Muhammad A rkoun, $\mathrm{N}$ alar Islam dan $\mathrm{N}$ alar M odern, hlm. 81.

${ }^{6}$ Al-Ghazâlî, al-M ustashfâ. Bandingkan dengan Alî ibn Abd al-Kâfî al-Subkî dan anaknya, al-Ibhâj fî Syarh al-M inhâj (Beirut: Dâr al-Kutub al-Ilmiyah, t.t.) cet. 1995/ 1416, I: 5.

7 Ta'ârud al-adillah adalah dua dalil atau lebih yang berlawanan. Ia biasanya diselesaikan melalui tarîh, dengan berpegang pada dalil yang lebih kuat dari dalildalil yang berlawanan tersebut atau dengan memastikan mana yang terlihat dari kedua dal il yang berlawanan tersebut tersebut yang dapat dijadikan pegangan.

8AI-Alwani, Source M ehodology, hlm. 5. 
Muhyar F anani

(873-950) dan disusul Ibn Sinâ (980-1037). Oleh karena itu, al-Farabi dikenal sebagai guru kedua logika (the second master) dan Ibn Sina sebagai guru ketiga (the third master). Sedangkan A ristoteles sebagai guru pertama (the first master). 9 Menurut A. Hanafi, penterjemahan besar-besaran buku-buku Yunani termasuk logikanya, telah berlangsung sebelum Yohana itu, yakni masa sebelum al-Syâfi î lahir (767 M), tepatnya antara tahun 750-850M.10 Imam al-Syafi i peletak dasar ilmu ushul figh nampak sangat mengenal logika A ristoteles ini. Jadi, cukup beralasan apabila al-Syâfi î dalam menyusun ilmu ini, juga berpedoman pada logika A ristoteles.11

Unsur-unsur ilmu al-Qur ân, dan Sunnah dapat dilihat pada pembahasan tentang periwayatan Hadîts secara ahad atau mutawâtir, kaidah pembacaan al-Qur ân yang standar, kriteria jarh (penolakan) dan ta' dîl (penerimaan), nâsikh-mansûkh,12 kondisi matan Hadîts dan perawinya, dan lain-lain.13 Sementara unsur ilmu figh bisa terlihat pada contoh-contoh kasus yang dipakai untuk memperjelas suatu teori atau kaidah. ${ }^{14}$ Unsur kaidah bahasa Arab, terutama bisa kita lihat pada bab metode istinbât yang menempuh jalan lafdziyah, bukan yang ma'nawiyah. Semua pembahasan kebahasaan dalam metode lafdziyah berpedoman pada kaidah-kaidah bahasa Arab.15 $\mathrm{Hal}$ ini terjadi karena sumber hukum utama, yakni al-Qur'ân dan Hadîts tertulis dengan bahasa Arab. Untuk memahaminya dengan benar, tentu harus berpedoman pada bahasa yang dipakainya, yakni bahasa Arab.

9M. Joesoep Sou'yb, Logika: Hukum Berfikir Tepat (Jakarta: Pustaka al-Husna, 1983), hlm. 236-8, dan hlm. 243.

10A. H anafi, Pengan tar Filsafat Islam, cet. 4 (Jakarta: Bulan Bintang, 1990), hlm. 40.

11A hmad Hasan, Pintu Ijtihad sebelum Tertutup, alih bahasa: Agah Garnadi, cet. 2.( bandung: Pustaka, 1994), hlm. 186.

12 Ini berawal dari konsep naskh, yakni menghapuskan atau membatalkan pemberlakuan suatu ketentuan hukum syara' dan menggantikannya dengan ketentuan hukum syara' yang baru. Ketentuan hukum syara' yang baru atau datang terakhir disebutr nâsikh, sedangkan ketentuan hukum syara' yang dihapus karena adanya ketentuan hukum syara' yang baru disebut man sûkh.

13Al-A Iwani, Source M ethodology, hlm. 5.

14 bid., hlm. 6.

15Muhammad A bû Zahrah, U shûl Fiqh (ttp.: Dâr al-Fikr al-Arabî, t.t.), hlm. 116; Khallâf. IIm U shûl, hlm. 140-1; A bd al-Karîm Zaydân, A I-W ajîz fî U shûl al-Fiqh (Beirut: Mu'assah al-Risâlah, 1994), hlm. 230. 
Unsur teologi (ilmu kalam) dalam ilmu ushul figh dapat terlihat pada pembahasan tentang asal suatu hukum (apakah dari Allâh atau akal manusia), konsep baik-buruk (apakah dari Allâh atau akal manusia). Demikian pula, bersyukur terhadap Allâh (apakah kewajiban dari-Nya atau sekedar akal manusia yang menentukan). ${ }^{16}$

Bernard Weiss melihat bahwa unsur teologi dalam ushul figh meliputi dua hal, yaitu persoalan teologi substantif (subtantive theological matters) dan persoalan epistemologi/metodologi (epistemological/ metodological matters). Persoalan pertama berkenaan dengan pengakuan atas Dzât Yang M aha Suci sebagai sumber hukum satu-satunya. ${ }^{17}$ Persoalan kedua berhubungan dengan teori pengetahuan yang membedakan secara tegas antara ilmu al-dlarûrî (necessary knowledge) yang diperoleh semata-mata pemberian Tuhan tanpa melalui proses penalaran dan pembuktian, dan ilmu al-muktasab (acquired/deduced knowledge) yakni ilmu yang diperoleh dari proses penalaran (reasoning) dan percobaan (demonstration). ${ }^{18}$ Dalam proses penalaran inilah dibutuhkan dalil sebagai premis. Premis bisa berwujud dalil teks (naqlî) atau dalil aqli.19 Proses penalaran yang akhirnya melahirkan suatu pendapat, sangat berperan penting dalam ilmu ushul figh.20 Akan tetapi, proses penalaran yang dimaksud adalah penalaran yang berbasis pada dalil teks (naqlî), bukan murni dalil aqli semata. ${ }^{21}$

Dalam khazanah intelektual Islam, ilmu ushul fiqh yang merupakan hasil gabungan dari berbagai ilmu itu, dianggap sebagai ilmu tentang kaidah atau pembahasan yang mengantarkan proses pengambilan hukum syara' praktis dari dalil-dalilnya yang terperinci.22 A tau dengan kata lain, ilmu tentang metode pengambilan

\footnotetext{
16Al-Alwani, Sou rce M erthodology, hlm. 5.

17Bernard Weiss, The Search for God's Law: Islamic Jurisprudence in The W ritings of Saif ad-D in al-A midi (Salt Lake City: University of Utah Press, 1992), hlm. 34-5.

$18 \mathrm{lbid}$., hlm. 38.

19l bid., hlm. 43.

20lbid., hlm. 42.

21l bid., hlm. 43.

22N adiah Syarif al-Umari, al-Ijtihâd fî al-Islâm: U shûluh, A hkâmuh, A fâquh, cet. 3 (Beirut: Muassasah al-Risâlah, 1987), hlm. 14; Lihat A bd al-Wahhab Khallâf, IIm U shûl Fiqh (ttp.: Dâr al-IIm, 1398/ 1978), hlm. 12.
} 
Muhyar F anani

hukum praktis dari dalil-dalilnya yang terperinci.23 Biasanya, kaidah (metode) pengambilan hukum syara' praktis itu, juga disebut sebagai dalil umum untuk membedakan dengan dalil khusus (terperinci) yang berupa teks (nash). ${ }^{24}$ Sesungguhnya ada penyempitan makna memang, dari yang semula ilmu tentang cara memahami agama menjadi ilmu tentang cara menggali hukum saja. Padahal hukum hanya sebagian kecil dari agama. Tetapi, memang begitulah para ulama bersikap dengan ilmu ushul figh. A kibatnya, ilmu ini dianggap hanya milik orang syarî̀ah saja. Orang ushul al-dîn tidak merasa memiliki. Di samping membahas kaidah (dalil umum), ilmu ushul fiqh sebenarnya juga membahas tentang tata cara menggunakan kaidah (dalil umum) itu, dan membahas orang yang menggunakan kaidah (dalil umum ) itu.

Definisi yang sempurna dan lengkap tentang ilmu ushul figh adalah definisi al-Qâdhî al-Baydhawî. Menurutnya, ilmu ushul fiqh adalah "Pengetahuan tentang dalil-dalil fiqh secara umum (bukan secara khusus), cara memanfaatkannya, dan pengetahuan tentang orang yang memanfaatkan dalil-dalil umum itu." 25

Demikianlah definisi ilmu ushul figh. Berbagai disiplin ilmu ternyata telah menyatu membentuk ilmu ushul figh. Oleh karena itu, ilmu ini memiliki kedudukan yang terhormat dalam khazanah intelektual Islam. Sejak tahun 1944, Syaykh Musthafâ Abd al-Râziq pertama kali melontarkan pikiran bahwa ilmu ushul fiqh adalah bagian dari filsafat Islam. Dialah orang yang pertama kali berpandangan demikian, yang ia tulis dalam bukunya, Tamhîd li Târîkh al-Falsafah al-Islâmiyah (1944). ${ }^{26}$ Pandangan ini didukung oleh banyak pakar, seperti Hâmid Thâhir dan Seyyed Hossein Nasr.27 Alasannya, kalau ilmu kalam dan tasawuf dianggap sebagai bagian

23Muhammad A bû Zahrah, U shûl Fiqh (ttp.: Dâr al-Fikr al-A rabi, t.t.), hlm. 7.

${ }^{24}$ Khallâf, IIm U shûl Fiqh, hlm. 12; Wahbah al-Zuhaylî, U shûl al-Fiqh al-Islâmî (ttp.: Dâr al-Fikr, t.t.), hlm. I:16. Zahrah, U sul Fiqh, hlm. 7; Al-Âmidî, al-Ihkâm fî U shûl al-Fiqh (Beirut: Dâr al-Kitâb al-A rabî, 1986), hlm. I: 23-4.

25Alî ibn A bd. al-Kâfî as-Subkî \& anaknya, al-I bhâj fi Syarh al-M inhâj, Juz I (Beirut: Dar al-Kutub al-Ilmiyah, 1995) hlm. 19.

26Hââmid Thâhir, M adkhal lî D irâsât al-F alsafah al-Islâmiyyah (Kairo: Hajar, 1985/ 1405), hIm. 31-2.

27Seyyed Hossein N asr, "TheM eaning and Role of Philosophy in Islam", dalam Studia Islamica, vol. 37, th. 1973, hlm. 62-3. 
dari filsafat Islam, maka ilmu ushul fiqh harus dianggap juga. Sebab metodologi pembahasannya mirip dengan ilmu kalam. Bahkan ushul fiqh juga membahas "dasar-dasar kalam", yang sebenarnya wilayah kajian ilmu kalam.

Di samping itu, kalau filsafat kenabian (prophetic philosophy) dianggap sebagai ciri khas filsafat Islam,28 maka ilmu ushul fiqh adalah wujud kongkrit filsafat kenabian itu. la mengantarkan manusia untuk dapat menangkap misi kenabian secara benar dan dapat dipertanggungjawabkan secara ilmiah.

Kalau dijadikannya al-Qur`ân dan Hadîts sebagai sumber inspirasi pemikiran filosofis merupakan ciri khas filsafat Islam,29 maka ilmu ushul figh adalah wujud nyata filsafat Islam. Ia meletakkan al-Qur'ân dan Hadîts sebagai sumber utama argumentasi hukum. Bahkan argumentasi rasional tidak boleh lepas dari payungan (naungan) al-Qur ân dan al-Hadîts. Suatu argumentasi yang tidak bisa direstui oleh al-Qur ân dan Hadîts, maka argumentasi itu akan dianggap produk luar Islam. Untuk mempertegas potret ilmu ushul fiqh di mata filsafat ilmu, kita perlu melihat kerangka dasar ilmu ini dalam kaca mata filsafat ilmu.

Dalam perspektif filsafat ilmu, terdapat 3 tiang penyangga suatu ilmu, yaitu, ontologi, aksiologi dan epistemologi. Ontologi adalah persoalan bidang kajian suatu ilmu. Aksiologi adalah persoalan fungsi suatu ilmu. Epistemologi adalah persolan sumber suatu ilmu.30 Marilah kita mulai dengan ontologi ilmu ushul fiqh.

\section{Kajian IImu Ushul fiqh: Tinjauan Ontologis}

Persoalan ontologi suatu ilmu adalah persoalan wilayah kajian suatu ilmu. Dengan kata lain, apa bidang kajian ilmu itu. Demikianlah para pakar filsafat ilmu berpendapat. Wilayah kajian ilmu ushul fiqh adalah kaidah-kaidah atau metode pengambilan

28Nasr, "The Qur'an and The Hadith as Source and Inspiration of Islamic Philosophy", dalam S.H. Nasr dan Oliver Leaman (eds), H istory of Islamic Philosophy (London-New York: Routledge, 1996) I: 36-7.

29lbid.

30Jujun S. Suria Sumantri, Filsafat IImu (Jakarta:PustakaSinar Harapan, 1993), hlm. 35. 
Muhyar F anani

hukum31. Kaidah-kaidah itu, biasanya disebut dengan dalil syara' yang kullî (dalil syara' yang umum). Misalnya berupa qiyâs dan kehujjahannya, batasan-batasan âm, perintah (amr) dan indikatornya, dan kaidah tentang larangan (nâhî). 32

Untuk memperjelas dalil syara' kullî ini, perlu kita singgung pula dalil syara' juz 'î. Dalil syara' juz 'î adalah teks-teks baik al-Qur 'ân maupun Hadîts. Sebagai contoh, ada teks (nash) dalam bentuk perintah (amr). Maka amr adalah dalil syara' kullî. Sedangkan teksnya yang dalam bentuk amr adalah dalil syara' juz '̂. Wilayah kajian ilmu ushul fiqh adalah dalil-dalil syara' kullî semacam itu, bukan juz 'î yang berupa teks (nas) itu.33 Karena dalil syara' juz î merupakan wilayah kajian ilmu fiqh. 34

Karena obyek kajian ilmu ushul figh adalah dalil-dalil syara' yang kullî (umum), maka ilmu ini membahas empat hal utama. Pertama, al-tsamrah (buah) yang meliputi hukum-hukum dan yang berkaitan dengannya. Kedua, al-mutsmirah (pemberi buah) yang meliputi dalil-dalil umum, yakni al-Qur'ân, al-Sunnah, al-ijmâ', alqiyâs, dan sebagainya. Ketiga, thuruq al-istitsmâr (metode mengambil buah yang meliputi metode kebahasaan dan metode kemaknaan. Keempat, al-mustatsmir (pengambil buah) yang meliputi kriteria orang yang berhak disebut mujtahid. 35

Dari elaborasi di atas, jelas bahwa ontologi (obyek kajian) ilmu ushul figh adalah metode (kaidah-kaidah) pengambilan hukum. Dalam persepektif filsafat ilmu, obyek kajian suatu ilmu harus berada dalam batas jangkauan pengalaman manusia dan tidak memasuki wilayah di luar itu, misalnya wilayah transendental (metafisik). 36 Metode pengambilan hukum juga berada dalam batas itu. Ia membantu manusia mengenal hukum Tuhan, sesuai dengan batas kemampuannya sebagai manusia. Pada prinsipnya, ilmu ini membantu manusia untuk bisa menangkap kehendak Tuhan yang

31 Zahrâh, U shûl, hlm. 8.

32A bd al-Wahhab Khallâf, Ilm U shûl al-Fiqh, (ttp.: Dâr al-IIm, 1398/ 1978), hlm. 13-4.

Lihat juga al-Alwani, Source M ethodology, hlm. 6.

33Khallâf, IIm U shûl, hlm. 14.

34 bid.

35Al-Ghazâlî, al-M u stashfâ, hlm. 1-554.

36lbid., hlm. 105. 
berasal dari wilayah transendental. Dengan demikian, ilmu ushul fiqh bukanlah ilmu yang berada dalam wilayah transendental. Ia tetap berada dalam wilayah jangkauan pengalaman dan penalaran manusia. Hanya saja, ia ingin menjadi jembatan bagi manusia dalam memahami maksud Tuhan yang transendental (metafisik).

\section{M anfaat IImu Ushul fiqh: Tinjauan A ksiologis}

Aksiologi merupakan persoalan fungsi suatu ilmu. Fungsi ilmu ushul figh adalah untuk membimbing manusia dalam menangkap maksud Tuhan secara benar. ${ }^{37}$ Oleh karena itu, segala kaidah dan teori dalam ilmu ini selalu diarahkan dalam rangka menangkap maksud Tuhan.

Dalam perspektif filsafat IImu, pada dasarnya, fungsi dan kegunaan suatu ilmu adalah untuk memecahkan persoalan yang dihadapi manusia. Oleh karena itu, ilmu berfungsi sebagai sarana untuk mensejahterakan manusia. ${ }^{38} \mathrm{IImu}$ ushul fiqh juga demikian. IImu ini berfungsi untuk membantu memecahkan problem yang dihadapi manusia dalam menangkap maksud Tuhan. Apabila manusia mampu menangkap maksud Tuhan dengan benar, ia akan dapat menjalani hidup dengan sejahtera baik di dunia maupun di akherat kelak.

Dalam perspektif filsafat ilmu, kesejahteraan manusia yang ingin diwujudkan oleh ilmu itu hanya sebatas kesejahteraan duniawi. Dalam arti, bagaimana manusia bisa sejahtera hidupnya selama di dunia ini dengan memahami dan menaklukkan alam sekitarnya, dirinya sendiri, dan manusia lain. Konsep kesejahteraan manusia, dalam perspektif filsafat ilmu, tidak pernah sampai pada konsep kesejahteraan di akherat kelak.

A ksiologi ilmu ushul figh, jelas berbeda dengan aksiologi ilmu pada umumnya. Ia berusaha mewujudkan kesejahteraan manusia

3TThâha Jâbir al-Alwânî, Source M ethodology in Islamic Jurisprudence (Herndon, Virginia: International Institute of IsImic Thought, 1415/ 1994), hlm. 88. Bandingkan dengan A hmmad al-Husarî, N azhâriyyah al- $\underline{H}$ ukm wa M ashâdir al-Tasyrî̀ fî U shûl al-Figh al-Islâmî (Kairo: Maktabah al-Kulliyatal-Azhariyyah, 1981/ 1401), hlm. 10. Lihatjuga Zahrah, U shûl al-Figh, hlm. 8.

38jujun, Filsafat IImu, hlm. 106. 
Muhyar F anani

baik di dunia ini maupun di akherat kelak.39

\section{Penutup}

Secara ontologis, obyek kajian ushûl figh adalah yaitu kaidahkaidah atau metode pengambilan hukum. Kaidah tersebut, biasanya disebut dengan dalil syara' yang kullî (dalil syara' yang umum) seperti metode qiyas dan batasan-batasan âmm, perintah (amr) dan indikatornya, serta kaidah tentang larangan (nâhy). Dalam perspektif filsafat ilmu, wilayah kajian tersebut masih berada dalam batas-batas jangkauan pengalaman dan penalaran manusia dan tidak berada di luar wilayah itu, yakni wilayah transendental. N amun demikian, ilmu ini membantu manusia untuk bisa menangkap kehendak Tuhan yang berasal dari wilayah transendental. Dengan demikian, ilmu ushul figh bukanlah ilmu yang berada dalam wilayah transendental.

Secara aksiologis, ilmu ini berfungsi untuk membantu memecahkan problem yang dihadapi manusia dalam menangkap maksud Tuhan, sehingga akhirnya ia akan dapat menjalani hidup dengan sejahtera baik di dunia maupun di akherat kelak. A ksiologi ilmu ushul figh ini, jelas berbeda dengan aksiologi ilmu pada umumnya yang hanya mengejar kesejahteraan duniawi. Dalam arti, bagaimana manusia bisa sejahtera hidupnya selama di dunia ini dengan memahami dan menaklukkan alam sekitarnya, dirinya sendiri, dan manusia lain. W allâh a'lam bi al-shawâb.

\section{D aftar Pustaka}

Alwânî, Tâha Jâbir al-. Source M ethodology in Islamic Jurisprudence. Herndon, Virginia: International Institute of Islmic Thought, 1415/ 1994.

Âmidî, Al-. al-Ihkâm fî U shûl al-Fiqh. Beirut: Dâr al-Kitâb al-Arabî, 1986.

Garisyah, Ali. Metode Pemikiran Islam. Manhaj at-Tafkîr al-Islâmî). Jakarta: Gema Insani Press, 1989.

Ghazâlî, Al-. al-M ustashfâ min 'Ilm al-U shûl,. Beirut: Muassah arRisalah, 1990.

39Al-Syâthibî, al-M uwâfaqât, Juz, hlm. 2. 
I Imu Ushul Figh

Hanafi,A. Pengantar Filsafat Islam, cet. 4. Jakarta: Bulan Bintang, 1990.

Hasan, Ahmad. Pintu Ijtihad sebelum Tertutup, alih bahasa: Agah Garnadi, cet. 2.. Bandung: Pustaka, 1994.

Husari, Ahmad al-. Nazhâriyyah al-Hukm wa M ashâdir at-Tasyrî̀ fi U shûl al-Figh al-Islâmî. Kairo: Maktabah al-Kulliyat alAzhariyyah, 1981/ 1401.

Khallâf, A bdul Wahhab. IIm U shûl al-Figh,. ttp.: Dâr al-IIm, 1398/ 1978.

Khallaf, A bdul Wahhab. IIm U sul Fiqh. ttp.: Dar al-IIm, 1398/ 1978.

Nasr, "The Qur'an and The Hadith as Source and Inspiration of Islamic Philosophy", dalam S.H. Nasr dan Oliver Leaman, History of Islamic Philosophy. London-New York: Routledge, 1996.

Nasr, Seyyed Hossein. "The Meaning and Role of Philosophy in Islam", dalam Studia Islamica, vol. 37, th. 1973.

Sou'yb,M. Joesoep. Logika: H ukum Berfikir Tepat. Jakarta: Pustaka alHusna, 1983.

Subkî, Alî b. Abd. Al-Kâfî al-. al-Ibhâj fi Syarh al-M inhâj. Beirut: Dar alKutub al-IImiyah, t.t.. cet. 1995/ 1416.

Subkî, Ali ibn A bd al-Kâfî al-. al-I bhâj fi Syarh al-M inhâj. Beirut: Dar alKutub al-IImiyah, t.t.. cet. 1995/ 1416.

Sulaymân, A bdul Hamîd A. A bû. Crisis in the M uslim M ind. HerndonVirginia: IIIT, 1414/ 1993.

Sumantri, Jujun S. Suria. Filsafat IImu. Jakarta: Pustaka Sinar Harapan, 1993..

Thâhir, ㅂâmid. M adkhal lî Dirâsât al-Falsafah al-Islâmiyyah. Kairo: Hajar, 1985/ 1405..

Umari, N adiah Syarif al-. al-Ijtihâd fi al-Islâm: U shûluh, ahkâmuh, afâquh, cet. 3. Beirut: M uassasah ar-Risalah, 1987., 14

Weiss, Bernard. The Search for God's Law: Islamic Jurisprudence in The Writings of Saif ad-D in al-Amidi. Salt Lake City: University of Utah Press, 1992. 
M uhyar F anani

Zahrah, Muhammad A bû .U shûl Fiqh. ttp.: Dâr al-Fikr al-A rabî, t.t..

Zaydân, Abdul Karîm. A I-Wajîz fî U shûl al-Fiqh. Beirut: Muassah arRisalah, 1994..

Zuhaylî, Wahbah al-. U shûl al-Figh al-Isâmî, Jilid I. ttp.: Dâr al-Fikr, t.t.. 